\title{
The giant cells in the synovial membrane
}

\author{
ARNOLD SOREN AND THEODORE R. WAUGH \\ From the Department of Orthopaedic Surgery and Rheumatic Diseases Study Group, New York University \\ School of Medicine, and Veterans Administration Medical Center, New York, NY, USA
}

SUMMARY Histopathological examinations of synovial tissues, obtained in 393 operations, disclosed the presence of foreign body giant cells or synovial giant cells or both in 51 cases. The presence of the former could be related to the occurrence of material foreign to the location, whereas for the latter group the coincidence of precipitated fibrin only was noted in a significant number of cases. The patients operated upon were classified by 10 diagnosed entities of joint disease, and the synovial giant cells, lying among synoviocytes or in the subsynoviocytic tissue, were observed in 8 of these categories. Thus no diagnostic significance could be attributed to the giant cells.

During inflammation of the synovial membrane giant cells may be observed among the histopathological changes. Whereas the giant cells of the Langhans type, ${ }^{1}$ with the characteristic arrangement of their nuclei in horseshoe shape, are an almost constant feature in special granulomatous inflammations (e.g., tuberculosis, sarcoidosis, fungus infections, and gout) of the synovial membranes, giant cells of other types have been described ${ }^{2-4}$ in nonspecific inflammations of the synovial membrane.

\section{Material and methods}

Specimens of synovial tissue were obtained from patients who had been extensively investigated by the Rheumatic Diseases Study Group, New York University Medical Center, and had been found not to present either in their history or in their clinical findings any suggestion of the above named granulomatous joint diseases. Patients with such indication were excluded from this study, ${ }^{5}$ during which 393 operations, a very small part for diagnostic reasons and the greater part for therapeutic reasons, were performed on joints affected by one of 10 identified entities of joint disease. The diagnoses were established on the basis of the history, all clinical data available, and laboratory studies which comprised: leucocyte count and differential count, sedimentation rate, sheep cell agglutination and

Accepted for publication 2 December 1980.

Correspondence to Dr Arnold Soren, Associate Professor of Orthopaedic Surgery, New York University School of Medicine, 550 First Avenue, New York, New York 10016, USA. agglutination inhibition, capillary latex fixation, C-reactive protein, antinucleid antibodies, uric acid in serum, L-E preparation, culture of microorganisms in blood and joint fluid, and radiographs. The patient's course subsequent to the operation was included in the case history.

The removed articular tissues were routinely fixed in buffered $10 \%$ formol and occasionally in Zenker's or Bouin's solution. The stain was haematoxylineosin, Mallory's phosphotungstic acid haematoxylin, Weigert-van Gieson's dye, and Masson's trichrome. The specimens stemming from the inner part of the joint capsule were examined for defined inflammatory, productive, and regressive changes, which were tabulated according to the degree of their occurrence in the clinically established entities of joint disease.

\section{Results}

One type of the giant cells observed in the synovial membrane comprised the foreign body giant cells aetiologically referable to the presence of material foreign to the location (bone spicules, fragments of hyaline cartilage, necrotic adipose tissue), but not to the body. These giant cells (Fig. 1) rarely occurred among and/or beneath synoviocytes, but mostly in the subjacent tissue. They were characterised by either the central location of their nuclei, which were surrounded by a broad rim of eosinophilic homogeneous cytoplasm, or the location of the nuclei in a corner, or the scattering of the nuclei throughout the cell. They varied in size from 28 to $65 \mu \mathrm{m}$ longest diameter, and contained 4 to 12 nuclei which were oval and had a sharply outlined membrane, 1 or 2 


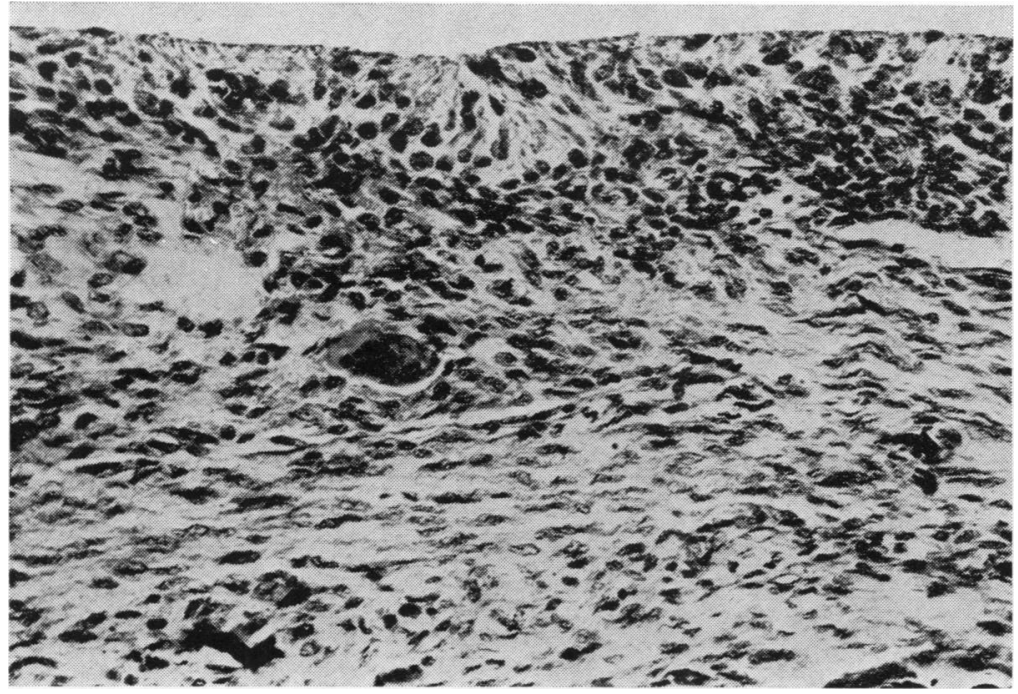

Fig. 1 Osteoclast giant cell lies in the vicinity of necrotic cartilage and bone spicules. The subsynoviocytic tissue is hypercellular with fibroblasts and fibrocytes. $(\times 120)$.

nucleoli, and rather evenly dispersed, dense chromatin powder. Some of them, of smaller size and with fewer nuclei, were readily identifiable as chondroclasts or osteoclasts (Fig. 1) by their proximity to fragments of cartilage or bone. On the other hand the giant cells close to portions of necrotic adipose tissue were substantially larger, having sometimes a diameter of $80-150 \mu \mathrm{m}$ due to distension of their cell body by a honeycomb work of small spaces (Fig. 2), which on histochemical staining with Sudan red, Nile blue sulphate, and potassium ferricyanide proved to be filled with lipids, fatty acids, and neutral fats. In the latter type of giant cells the nuclei were conspicuously pushed toward the periphery.

Another and more often observed type of giant cell was designated synovial giant cell by Grimley and Sokoloff. ${ }^{6}$ These cells occurred in small, loose groups and varied in size from 25 to $75 \mu \mathrm{m}$, but mostly were $45 \mu \mathrm{m}$ or less (Fig. 3). They were ovoid or round, and had a peripherally denser cytoplasm from which a few plump processes extended in all directions; the

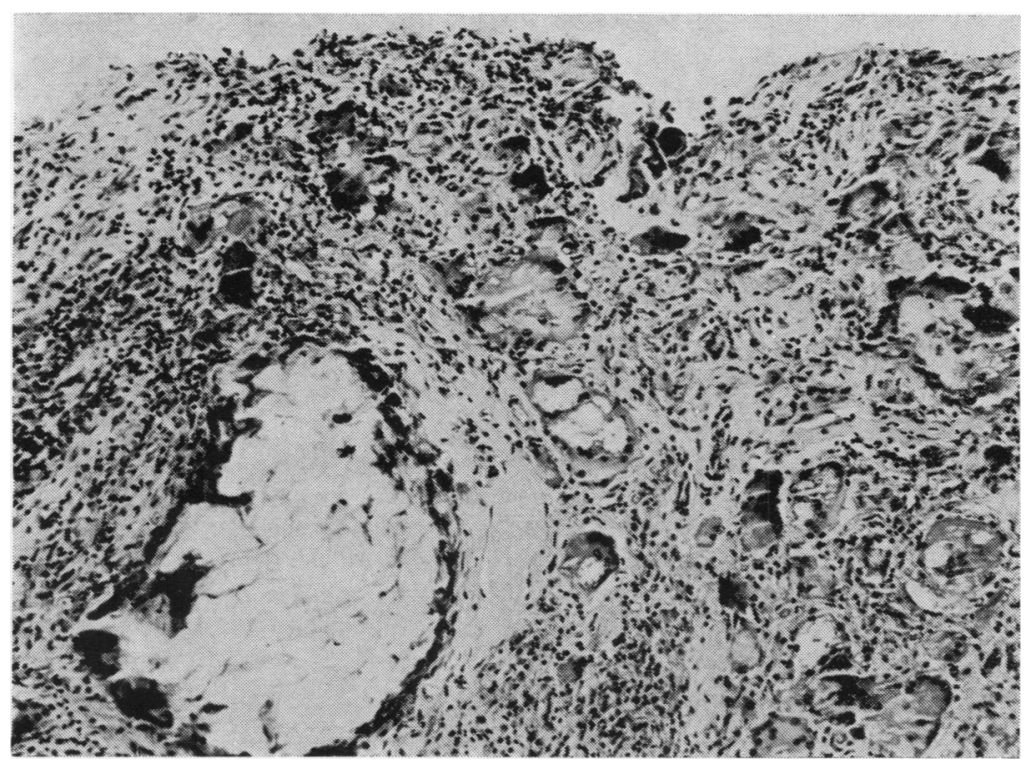

Fig. 2 Lipid-laden foreign body giant cells lie in the subsynoviocytic tissue. The latter is hypercellular with fibrocytes and is infiltrated by lymphocytes. $(\times 74)$. 


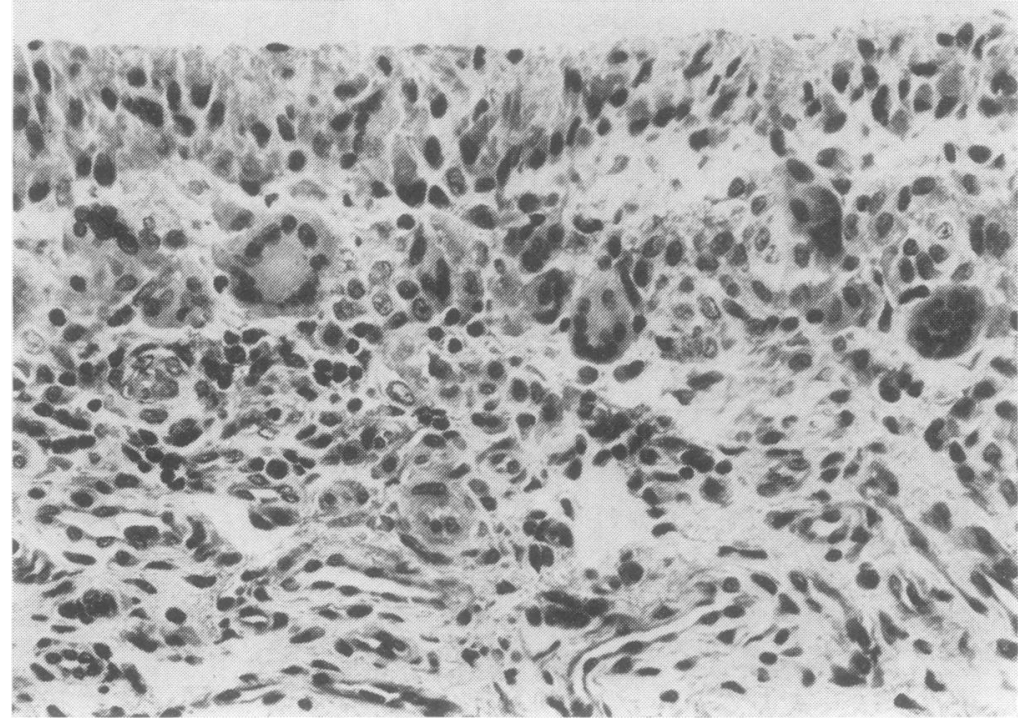

Fig. 3 Synovial giant cells of various stages of development lie directly beneath synoviocytes and in the subsynoviocytic tissue. $(\times 185$. central cytoplasm sometimes contained fine granules or vacuoles. Their vesicular, rather uniform nuclei numbered from 2 to 12 , rarely up to 30 , but most commonly from 3 to 8 , and resembled those of hypertrophic synoviocytes, justifying thus the designation given by Grimley and Sokoloff. ${ }^{6}$ The nuclei were ovoid, 3-5 $\mu \mathrm{m}$ long and 2-3 $\mu \mathrm{m}$ wide, and contained 1 to 2 nucleoli and several irregularly distributed chromatin particles (Fig. 3). In the majority $(65 \%)$ of the cases of this study with synovial giant cells the nuclei were peripherally situated, leaving the central cytoplasm free (Fig. 3). In a smaller number $(33 \%)$ the cells had irregularly distributed nuclei, and in $2 \%$ the cells had centrally situated nuclei. The synovial giant cells were located in $50 \%$ of the cases in the synoviocyte cover, in $24 \%$ in the subsynoviocytic tissue, and in $26 \%$ in botb zones (Fig. 3). In the first location the giant cels: either lay amid or underlay hypertrophic synovioe cytes, but retained contiguity with the latter. In the second location the giant cells were separated from the deep border of the synoviocytes by a broader layer of collagen fibres.

As a variety or the predecessors probably of the synovial giant cells, some cells characterised by their larger size of 22-30 $\mu \mathrm{m}$ (Fig. 4), yet the presence of 1

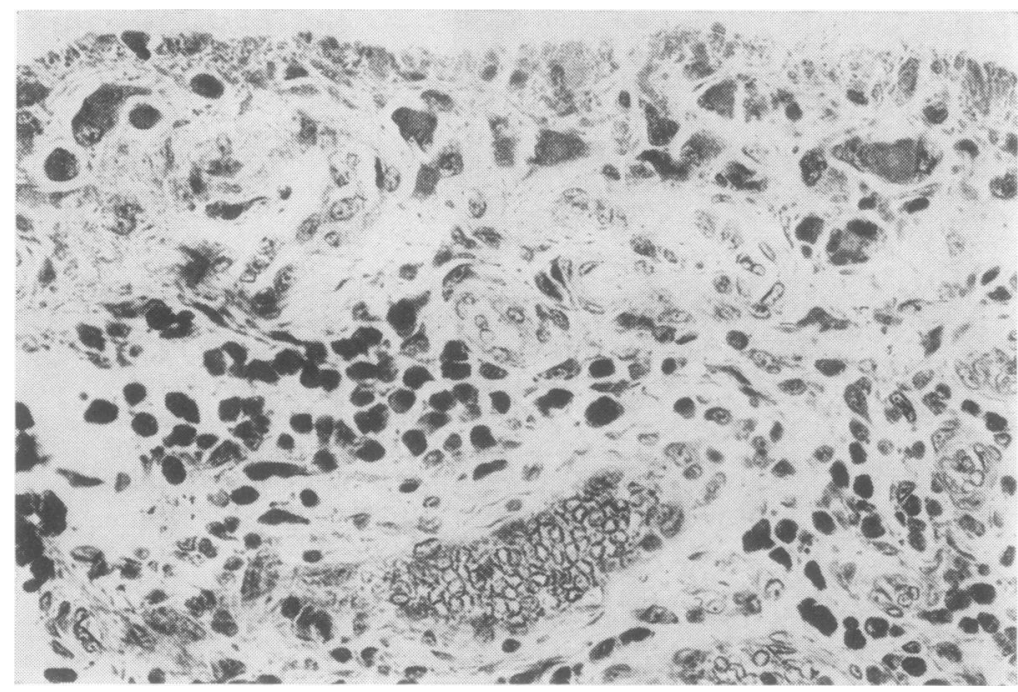

Fig. 4 Substantially larger cells, resembling synoviocytes, with 1 or 2 nuclei lying amid or beneath the synoviocytes. $(\times 185)$ 
nucleus only, were observed directly beneath the synoviocytes and amid fibrocytes and fibroblasts. They were conspicuous by their plump shape and appeared to represent the initial stage of the giant cells before they underwent multiplication of the nuclei and further augmentation of the cytoplasmic mass.

\section{Discussion}

The position of the giant cells amid and under the synoviocytes, and the structural resemblance of their nuclei to those of the neighbouring synoviocytes, suggest that these giant cells originated directly from synoviocytes. The subsynoviocytic giant cells probably arose from fibroblasts, which are considered to be the progenitors also of the synoviocytes.

The cause of development of the synovial giant cells appears to lie in stimuli by noxious agents which elicit the complex of responses termed inflammation. McEwen ${ }^{7}$ indicated that the multinucleated cells participating in the formation of granulomata in various rheumatic lesions probably arise from undifferentiated mesenchymal elements of loose connective tissue. The increased number of their nuclei possibly derives from repeated amitotic divisions of the nucleus ${ }^{8-10}$ at which the cytoplasm did not participate in the division. The uniformity in appearance of the cytoplasm and the lack of any subdivision or indentation of the cell membrane support such a view. However, the experiments of Cohn and Benson ${ }^{11}$ and Falke and Richter ${ }^{12}$ indicated that the giant cells develop by fusion of mononuclear cells from which the nuclei migrate and the cell borders disappear. Similarly, the cytophotometric studies of Papadimitriou and Cornelisse ${ }^{13}$ indicated that fusion of mononuclear cells is the process which leads to formation of multinucleated cells. Capellaere ${ }^{14}$ arrived in his extensive review at the conclusions: (1) that fusion is the mechanism leading to formation of giant cells which develop in the proximity of, among others, necrosed collagen or precipitated fibrin, and (2) that they appear rather early in the inflammatory reaction and show increase of defensive potentialities by combining the elements of several cells.

Grimley and Sokoloff ${ }^{6}$ observed synovial giant cells in synovitis of various kinds but did not find them 25 to $100 \mu \mathrm{m}$ below the synovial surface in any condition other than seropositive rheumatoid arthritis. Nevertheless, conservatism about the diagnostic specificity of the giant cells in the latter location appears justified according to Grimley and Sokoloff. ${ }^{6}$ On the other hand Donald and $\mathrm{Kerr}^{3}$ were unable to find similar giant cells in joint trauma, osteoarthritis, or other conditions except for active rheumatoid arthritis.

In Soren's study ${ }^{5}$ synovial giant cells among synoviocytes as well as in the subsynoviocytic zone were observed not only in rheumatoid arthritis and in the rheumatoid-like entities such as synovitis in ankylosing spondylitis and synovitis in psoriasis, but also in other diagnostic categories such as post-traumatic synovitis and synovitis in osteoarthritis (Fig. 5 and Table 1). Whereas the synovial giant cells occurred more often within or directly beneath the synoviocyte cover than in the somewhat deeper subsynoviocytic tissue, in whatever location they occurred they could not be considered diagnostic of rheumatoid arthritis, although they occurred more frequently in synovitis in definite and classical rheumatoid arthritis and in rheumatoid-like entities such as synovitis in ankylosing spondylitis, and in synovitis in psoriasis, than they did in other categories of synovitis. The greater

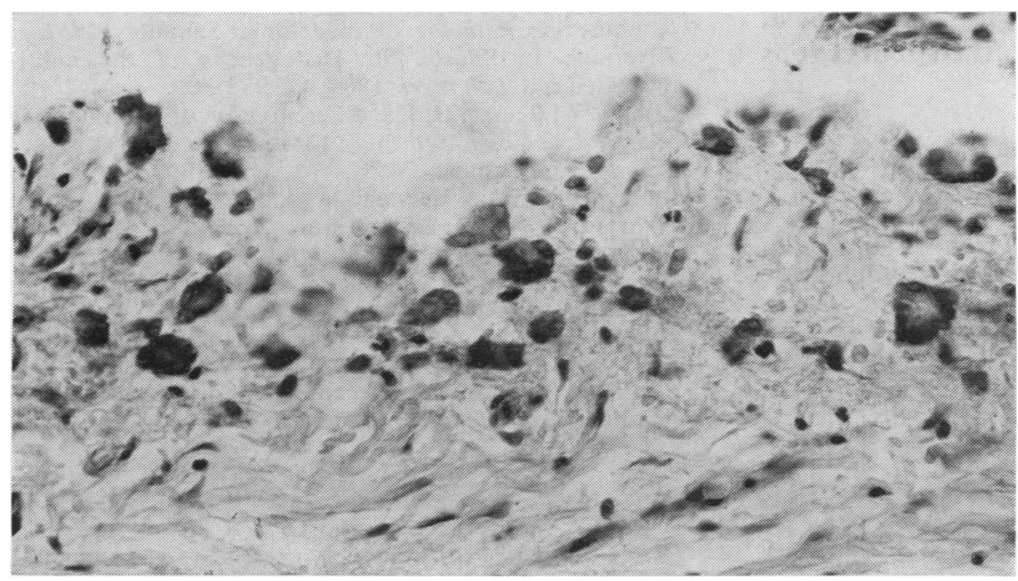

Fig. 5 Synovial giant cells lie amid synoviocytes and in the subsynoviocytic tissue. $(\times 185)$. 
Table 1 Incidence of giant cells in the synovial membrane and of some concurrent histopathological changes

\begin{tabular}{|c|c|c|c|c|c|c|c|c|c|c|c|}
\hline & & $\begin{array}{l}\text { Po. } \\
\text { syn. }\end{array}$ & $\begin{array}{l}\text { Syn. } \\
\text { os. }\end{array}$ & $\begin{array}{l}\text { Syn. } \\
\text { R.s. }\end{array}$ & $\begin{array}{l}\text { Syn. } \\
\text { i.d. }\end{array}$ & $\begin{array}{l}\text { Syn. } \\
\text { a.s. }\end{array}$ & $\begin{array}{l}\text { Syn. } \\
\text { ps. }\end{array}$ & $\begin{array}{l}\text { Syn. } \\
\text { j.r. }\end{array}$ & $\begin{array}{l}\text { Syn. } \\
\text { p.r. }\end{array}$ & $\begin{array}{l}\text { Syn. } \\
\text { d.r. }\end{array}$ & $\begin{array}{l}\text { Un. } \\
\text { syn. }\end{array}$ \\
\hline & 43 & 74 & 9 & 7 & 17 & 13 & 23 & 47 & 127 & 33 \\
\hline $\begin{array}{l}\text { Total cases } \\
\text { Synovial giant cells in synoviocyte } \\
\text { cover }\end{array}$ & $\begin{array}{l}+ \\
++ \\
+t+\end{array}$ & 1 & 4 & & & 1 & 2 & 1 & 2 & $\begin{array}{l}8 \\
2 \\
1\end{array}$ & \\
\hline $\begin{array}{l}\text { Synovial giant cells in subsynoviocytic } \\
\text { tissue }\end{array}$ & $\begin{array}{l}+ \\
++ \\
++t\end{array}$ & $\begin{array}{l}2 \\
1\end{array}$ & 1 & & & 1 & 1 & 1 & 2 & $\begin{array}{l}1 \\
2 \\
1\end{array}$ & 1 \\
\hline Synovial giant cells in both locations & $\begin{array}{l}+ \\
++ \\
+++\end{array}$ & 1 & $\begin{array}{l}1 \\
2\end{array}$ & & & 1 & 1 & & & $\begin{array}{l}2 \\
4 \\
2\end{array}$ & \\
\hline $\begin{array}{l}\text { Foreign body and other types of } \\
\text { giant cells in subsynoviocytic } \\
\text { tissue }\end{array}$ & $\begin{array}{l}+ \\
++ \\
+t+\end{array}$ & $\begin{array}{l}1 \\
1\end{array}$ & $\begin{array}{l}3 \\
1\end{array}$ & & & & & & & 1 & \\
\hline \multicolumn{2}{|l|}{$\begin{array}{l}\text { Syn. giant cells and syncyte } \\
\text { hypertrophy }\end{array}$} & 1 & 8 & & & 3 & 4 & 2 & 4 & 23 & 1 \\
\hline \multicolumn{2}{|l|}{$\begin{array}{l}\text { Syn. giant cells and syncyte } \\
\text { hyperplasia }\end{array}$} & 1 & 8 & & & 1 & 4 & 2 & 3 & 20 & 1 \\
\hline \multicolumn{2}{|l|}{ Syn. giant cells and organised fibrin } & 1 & 1 & & & 1 & 3 & 1 & 3 & 15 & 1 \\
\hline \multicolumn{2}{|l|}{ Syn. giant cells and fibroblasts } & 1 & 3 & & & & 4 & 1 & 3 & 19 & 1 \\
\hline \multicolumn{2}{|l|}{$\begin{array}{l}\text { Syn. giant cells and increased } \\
\text { fibrocytes }\end{array}$} & 1 & 9 & & & 2 & 3 & 2 & 4 & 20 & 1 \\
\hline \multicolumn{2}{|c|}{ Syn. giant cells and intra-artic. steroids } & & & & & & & & & 1 & \\
\hline
\end{tabular}

Po.syn. = Post-traumatic synovitis.

Syn. os. = Synovitis in osteoarthritis.

Syn. R.s. = Synovitis in Reiter's syndrome

Syn. i.d. = Synovitis in intestinal diseases.

Syn. a.s. = Synovitis in ankylosing spondylitis.

Syn. ps. = Synovitis in psoriasis.

Syn. j.r. = Synovitis in juvenile rheumatoid arthritis.

Syn. p.r. = Synovitis in possible and probable rheumatoid arthritis.

Syn. d.r. = Synovitis in definite and classical rheumatoid arthritis.

Un. syn. = Unclassified synovitis.

incidence of the synovial giant cells in the former diseases might be partly related to the greater frequency of fibrin precipitated on or in the synovial membrane. Consistent with this assumption is the fact that the presence of synovial giant cells was associated in about $50 \%$ of the cases with the occurrence of organised fibrin on the synovial membrane (Table 1).

In view of the contention that intra-articularly injected steroids elicit the development of giant cells, Table 1 shows that out of the 51 cases with synovial giant cells in only 1 case were intra-articular injections with hydrocortisone administered.

\section{References}

1 Langhans $T$. Über Riesenzellen mit wandstandigen Kernen in Tuberkeln und die fibrose Form des Tuberkels. Virchows Arch Pathol Anat 1868; 42: 382-404.

2 Collins D H. Pathology of Articular and Spinal Diseases. Baltimore: Williams and Wilkins, 1950.

3 Donald H F, Kerr J F R. Giant cells in the synovium in rheumatoid arthritis. Med J Aus 1950; i: 761-2.
4 Hirohata K, Kobayashi J. Fine structure of the synovial tissue in rheumatoid arthritis. Kobe J Med Sci 1964; 10: 195-225.

5 Soren A. Histodiagnosis and Clinical Correlation of Rheumatoid and Other Synovitis. Stuttgart: Thieme, Philadelphia: Lippincott, 1978.

6 Grimley P M, Sokoloff L. Synovial giant cells in rheumatoid arthritis. Am J Pathol 1966; 49: 931-46.

7 McEwen C. Cytologic studies on rheumatic fever. I. The characteristic cell of the rheumatic granuloma. J Exp Med 1932 ; 55 : 745-59.

- Morehead K P. Human Pathology. An Introduction to Medicine. New York: McGraw-Hill, 1965.

9 Robbins S L. Pathology. Philadelphia: Saunders, 1967.

10 Silverman L, Shorter R. Histogenesis of the multinucleated cell. Lab Invest 1963; 12: 985-90.

11 Cohn Z A, Benson B. The differentiation of mononuclear phagocytes. J Exp Med 1965; 121 : 153-69.

12 Falke D, Richter D E. Mikrokinematographische Studien über die Entstehung von Riesenzellen durch $N$ Herpes-B Virus in Zellkulturen. Arch Ges Virusforsch 1962; 11: 73-85.

13 Papadimitriou J M, Cornelisse C J. A cytophotometric and autoradiographic study of DNA synthesis in macrophages and multinucleated foreign body giant cells. J Reticuloendothel Soc 1970; 18: 260-79.

14 Cappelaere $P$. Cellules géantes et processus inflammatoires. Lille Med 1967; 12: 1222-48. 